This is a post-print version of the following article: Orero, Pilar; Matamala, Anna (2007) Accessible Opera: Overcoming Linguistic and Sensorial Barriers. Perspectives. Studies in Translatology, 15(4): 427-451.

DOI: 10.1080/13670050802326766

http://www.tandfonline.com/doi/full/10.1080/13670050802326766\#.U0afL-Z_sWU

\title{
Accessible Opera: Overcoming Linguistic and Sensorial Barriers
}

The desire to make media available for all has been rapidly accepted and implemented by most European countries. Opera, as one of the many audiovisual representations, also falls under the category of production which needs to be made accessible and this article aims to analyse how opera has gone through a complete transformation to become a cultural event for all, overcoming not only linguistic but also sensorial barriers. The first part of the article analyses the various forms of translation associated with opera and the main challenges they entail. The second presents different systems used to make opera accessible to the sensorially challenged, highlighting their main difficulties. Examples from research carried out at the Barcelona's Liceu opera house are presented to illustrate various modalities, especially audio description. All in all, it is our aim to show how translated-related processes have made it possible to open opera to a wider audience despite some initial reluctance.

\section{Overcoming linguistic barriers}

Performing opera in the source language or in the language of the audience has been a major discussion in the literature of Translation Studies - and references are found from as distant fields as Music Studies and as early as the beginning of the $20^{\text {th }}$ century (Spaeth 1915), but it is Nisato (1999:26) who provides a comprehensive summary of the current three possibilities in opera performance, which in our opinion can perfectly coexist: "performing the opera in its original language and provide the listener with either a synopsis or translated libretto, to perform in the original language and make use of surtitles, or to perform a sung translation of the work". The many arguments for and against found in the literature are valid today, but one must admit that translation in either form has helped to bring opera closer to the audience and the modality chosen depends on fashion, taste and socio-cultural issues (Mateo 1998).

\subsection{The translation of libretti: reading and singable translations}

The first obvious difficulty in accessing an opera, both for the audience and the singers, is the language of the original. This is why libretti have been translated bearing in mind the many functions they may serve. When they are to be used as a working document by singers who want to grasp the meaning of the lyrics, translators sometimes offer a wordby-word translation of the libretto (Sario \& Oksanen 1996), a version which never reaches the audience. Yet some libretti translations are made exclusively for reading purposes and hence fall under the category of literary translations (Desblache 2004). Burton \& Holden (2005) name them "straight libretto translations" and they can be found as the printed matter on the boxes of vinyl recordings, CDs, DVDs and programmes. As with any literary translation, they may go from verse to full prose versions (Low 2002), entailing various challenges. It is not the same to offer an 
unrhymed version like recreating the poetry of the original: sometimes content is prioritised over form. Literal translated libretti can be considered a first step towards overcoming language barriers, but they can only be useful in grasping the gist of the opera if the audience reads them before the actual performance undertaking a documentation process.

Another modality is the translation of libretti in order to create what it has been coined as a "singable" version in the target language. These versions are produced in order to be sung and facilitate access to the opera when performed. The main challenge in this case is making the target text fit the many demands of both the target language and its format: the music. In order to fulfil these requirements, Low (2005) proposes large doses of flexibility and refines a previously outlined proposal, the so-called pentathlon principle, a balancing of five criteria: singability, sense, naturalness, rhythm and rhyme. Many translators have reflected on these issues, as summarised next.

Apter (1985), who usually translates rhymed libretti into rhymed English with Herman makes reference to the fact that music and words must fit. Apter deepens in the use of rhyme along with other rhetorical devices such as assonance and alliteration. He also looks at the translator's toughest challenge: matching foreign rhythms, taking into account both the stress and the burden (the time it takes to say a syllable in normal speech). The many and varied vocal constraints, fixed prosody, and the coexistence of two aural systems (musical and verbal) are later summarised as the main challenges by other studies such as Apter (1989), Herman and Apter (1995) and Gorlée (1997). One more issue is raised by Glick (1987: 221) when stating that translators must "make the speech of each of the characters as believable as possible", which is a matter of decorum also discussed by Apter \& Herman (2002) and Kolago (2004).

Alonso Otero (2000-2001) also reflects on his work as a translator for libretti, in this case from Italian into Spanish. Four directives are given to tackle translations: (i) to translate from the music score so all the stage instructions are respected; (ii) to respect, as much as possible, the rhythm imposed by the music, even though it may be at the expense of the rhyme; (iii) to respect the poetical feeling, avoiding compensation by explanation, and (iv) to portray, when needed, the archaic tone, the social differences in the register of the vocabulary and in all the features of a text aimed for the stage.

Another interesting element is fidelity or equivalence in opera translation. Desblache (2004) points to the many constraints linked to musical demands that opera translation presents, dooming an equivalence which is qualified as "not desirable". Desblache briefly illustrates how adaptations are necessary by means of her French translation of Benjamins Britten's Albert Herring, composed in 1947. "Capture the spirit of the text, but [to] forget the source words" was the advice given to the author by the librettist Eric Crozier, an advice that was indeed followed because "many aspects of the original version could not be transferred: textual contrasts, thought out in collaboration with the composer to fit the music, particularly those between rhyming and prose; cultural references to proverbs, food, social structures, all essential to humour. Loss of equivalence was unavoidable at times, but strategies were found to convey the essential aspects of the work" (ibid: 30). Desblache (2008) discusses further problems related to cultural equivalence, humour and rhyming. The need to be familiar with many historical and cultural references, as well as with certain archaisms no longer understandable by contemporary speakers of the language, is an issue also stressed by Burton (2005). 
Regarding further skills needed by a good opera translator, Apter considers a must the "knowledge of music, of vocal technique, of prosody, and of rhyme - plus some knowledge of foreign language... Knowledge of playwriting and stagecraft also helps." (Apter 1985: 318). The fact is that opera in singable translation has always been under attack by those who translate as well as from reticent audiences. Apter \& Herman (1995: 26) go as far as commenting "translations are bad because all concerned - the translators, the performing companies, and the audiences - want them that way".

\subsection{Opera surtitling and subtitling}

Another possible means of overcoming the linguistic barriers encountered by the audience are through adding subtitles and surtitles - also called over-titles - to the production. This practice enables the audience to read the translation and follow the words sung in an unknown language at the same time the opera is performed. Subtitling or surtitling has become increasingly popular and both Sario \& Oksanen (1996) and Desblache (2008) have proved by means of surveys that the audience is generally hungry for surtitles. In fact, even in intralingual surtitling patrons express their satisfaction because the words being sung are not always easy to understand (Fenton 2003).

According to Burton (forthcoming), subtitles for opera on film have been around almost as long as cinema itself. On television the first subtitles for opera appeared in the early 1970s and were later included in VHS or DVD editions. The subtitling of operas on TV is what probably inspired opera surtitles, which can be defined as a "kind of caption displayed above the stage during a live performance, giving a written translation of the audible words - though not all of them - which are being sung at any given moment. The display is in white letters on black, or pale coloured letters on a dark background" (Low 2002: 97).

A historical overview of this practice which originated around 1984 in Canada $^{1}$ is found both in Mateo (2002) and Low (2002), who state that surtitling solved two problems of opera: intelligibility and cost. As for their relationship with subtitles, ${ }^{2}$ Low (ibid) finds the following similarities:

- They both produce a legible version of verbal material

- There are size and time constraints: condensation is important. Nevertheless, the constraints of time are less than in film subtitling.

- The TL version must be easy to read

- Ambiguity must be avoided

- Each title must be a self-contained statement and, if impossible, it should be break it up with suspension points

- Clumsy line-breaks should be avoided if the title exceeds one line

- Basic punctuation should be used and full stops at the end of titles should be ignored.

- Obvious repetitions should be obviated.

\footnotetext{
${ }^{1}$ Burton (forthcoming) explains that, although not well documented, it seems the first live titles in an opera house were in Hong Kong in the early 1980s, but since they were in Chinese, they were displayed vertically at the side of the stage.

${ }^{2}$ Sario \& Oksanen (1996: 192) also compare live surtitling of operas and television subtitling of operas.
} 
- Brief unambiguous utterances should be omitted, especially if gestures carry the message.

Nevertheless, subtitles for opera on film, TV, video or DVD and live surtitles demand different requirements:

TV subtitles need to be on the screen for as little time as possible - not much longer than it takes to read them (ten seconds is a useful maximum); with 'close-up' television pictures, it is sometimes possible to subtitle tiny asides or snatches of text, or to single out one character in a large ensemble. In contrast, live surtitles need to be painted with a broader brush; the text should hang above the audience's heads as a guide to comprehension, not distracting their attention by cramming in too much text or by flashing past too quickly. (Burton \& Holden 2005).

Surtitling can be considered from three points of view, as suggested by Mateo (2002):

a) Technically, surtitles can be projected by means of two different systems (Mateo 2002: 54), with different costs: slide projection or software system. As put by Hay (1998), "format computer operated LED displays or computer controlled video projection on a screen suspended above the proscenium arch or at the back of the stage. Overhead projectors are sometimes used in small theatres with the addition of a computer controlled projection pad." In all instances surtitles are projected live, a distinctive feature compared to recorded subtitles of opera on TV, for example, which compels operators to adapt to any improvisations.

b) Ideologically and socially, Mateo (2002) considers that surtitles have made opera more accessible to a wider audience, overcoming a linguistic barrier - even in intralingual surtitles. This aspect is tightly linked to the elements that will be later analysed, because media accessibility has made it possible to widen even more the audience including those sensorially impaired.

c) Textually, Mateo (2002) argues that the surtitler generally works from a translated libretto, which is then adapted to conform to a certain performance. Yet, Low (2002) considers that full prose versions of the libretto and singable versions cannot be reconverted into surtitles because too much editing would be needed. In fact it is a matter of both: time available and the financial budget of each performance.

As for the main difficulties of this transfer mode, Mateo (2002) presents some translation guidelines from different surtitling companies which can help us gain some insight into the skills needed to be a good surtitler. Tri-Cities Opera Company, for example, considers it crucial to control how much is said (not too much, not too little), how to say it and when to say it, whilst Aria Nuova's strategy is to stress comprehension rather than fidelity, using a standard language with just a few archaisms if necessary. As for SURTITLES ${ }^{\text {TM } 3}$, its main aims are (i) to use different native editors to proof for subtle nuances of language and check the English content, (ii) program cues to change at varying speeds to reflect the music, thereby rendering the titles unobtrusive and fluid, and (iii) accurately reflect each particular production.

Indeed, another important feature is the relationship of the subtitles with the mise-enscène. As already put forward by Hurt (1996), surtitles are part of the Gesamtkunstwerk

\footnotetext{
${ }^{3}$ http://www.surtitles.com/translate.html
} 
opera and should be produced by translators in cooperation with specialists from various departments. Using examples from Wagner's Siegfried, Hurt (1996) demonstrates that the translation of surtitles is determined by technological factors but also by the production itself: she shows how two different productions based on the same opera produced two completely different surtitles. In this line, Sario and Oksanen (1996), experienced surtitlers working at Finland National Opera, consider that elements of the libretto obviated in the mise en scène should be eliminated in surtitles, but other authors are in favour of translating the dramatic text (Virkkunen 2004: 93).

Finally, further problems to be solved by surtitlers are stressed in the literature by both professionals and academics (Burton 2001 \& forthcoming, Dewolf 2001, Durastanti 2004, Nisato 1999, Low 2002, Mateo 2002, Sario \& Oksanen 1996): condensation, ensembles, variation in the density of words, repetitions, melismas, poetic or overblown styles, archaisms, synchronisation, adaptation of cultural, humoristic and historical references, the need to create comprehensible surtitles that form a logical unit, the avoidance of previous translations and the avoidance of representing in writing both onomatopoeias and all sounds which are clearly recognizable by the public, since they may detract attention to the performance.

Though many studies have been published on the matter, many issues are still in need for research such as the presentation of surtitles: how many characters per line? How many lines? How long should a surtitle be on display? What happens with the surtitle when the line sung is repeated? Should the surtitles be the same when projected over the proscenium rather than when shown on an individual screen? We may find ourselves with three different screenings in one opera house, such as Barcelona's Liceu. In Fig. $1^{4}$ we find the screens placed in those seats in the two top floors where there is little or no vision of the stage. In Fig. 2 we find the two different models for screen found in all the seats with full view of the stage. And finally, in Fig. 3 we can see the proscenium with the surtitles.

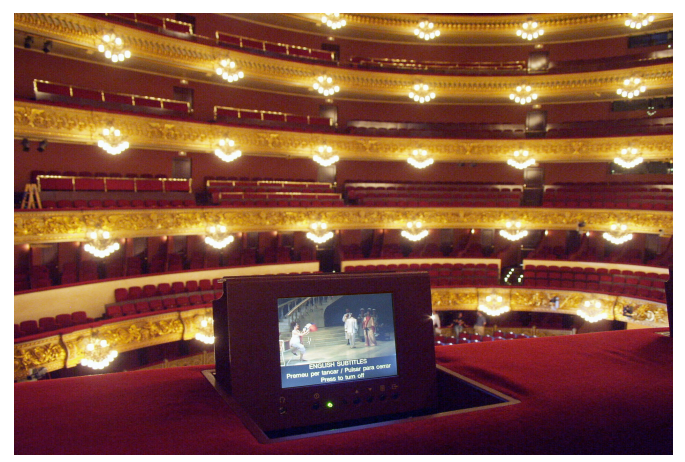

Fig.1 Screen at Barcelona Opera House Liceu

\footnotetext{
${ }^{4}$ We wish to thank Liceu for allowing us to reproduce these pictures and also to Miquel Bofill, the photographer who holds the copyright.
} 


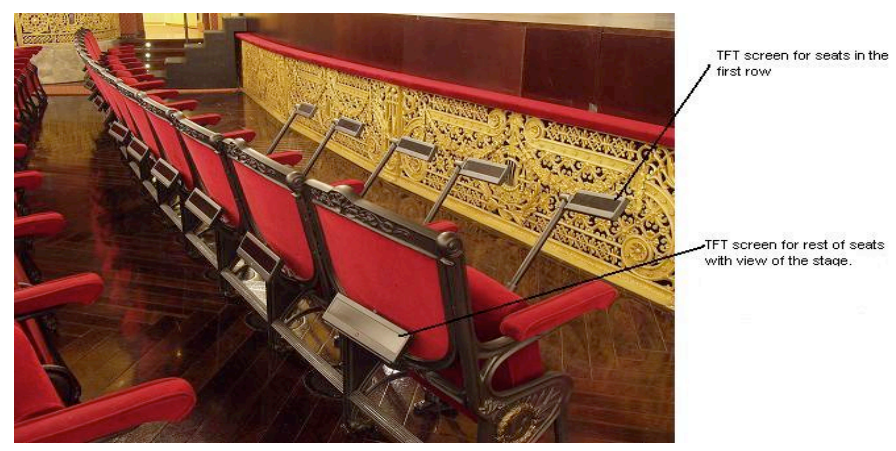

Fig.2 Screens at Barcelona Opera House Liceu.

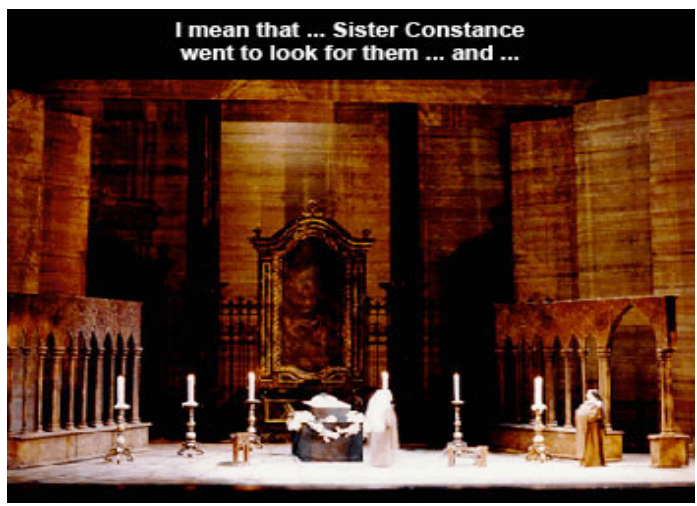

Fig.3 Surtitles or supertitles in the The Canadian Opera Company, Dialogues des Carmelites, 1997.

The ideal subtitles, using Low's (2002) four priorities, are those that fulfill the following requirements: the translation helps the audience follow the plot, it helps the audience understand the emotions of the characters, it fits in with the concept of each particular production, and remains relatively unobtrusive.

To sum it up, both singable versions and intralingual and interlingual subtitles/surtitles make it possible to gain access to operas, but the difficulties associated with each modality are various, as summarised in the following chart:

\begin{tabular}{|l|l|}
\hline Challenges in singable translations & Challenges in surtitling \\
\hline - Words must fit the music. & - Comprehensibility of surtitles \\
- Singability and vocal constraints due & - Synchronisation \\
- to anatomical features. & - Concision and clarity \\
- Rhythm. & - Adaptation to the staging \\
- Repetitions. & - Dealing with repetitions \\
- Naturalness. & - Dealing with ensembles \\
- Making sense, meaning. & - Dealing with an overblown language \\
- Character delineation through & - Faithfulness \\
language (registers). & - Melismas (setting several notes to a \\
\hline
\end{tabular}




\begin{tabular}{|c|c|}
\hline 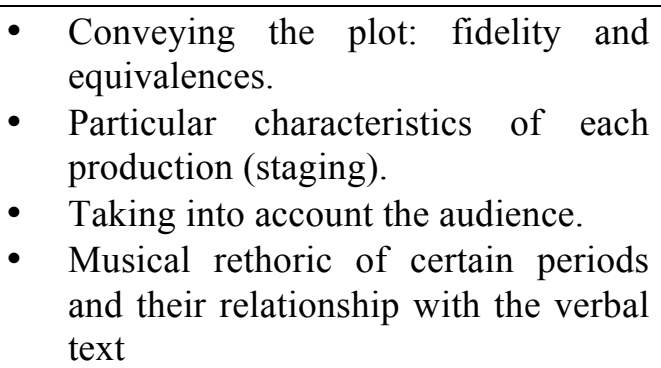 & $\begin{array}{l}\text { single syllable of text) } \\
\text { The target version presents rhymes and } \\
\text { other phonic features } \\
\text { - Usage of emphasis which is not possible } \\
\text { in speech } \\
\text { - Need to adapt to a live performance, } \\
\text { remaining unobtrusive } \\
\text { - Visibility of the translator }\end{array}$ \\
\hline
\end{tabular}

\section{Overcoming sensorial barriers}

Although singable versions and subtitles/surtitles have widened the audience of opera, there are still other barriers to break: those that affect people with different impairments. Improved accesses to the opera houses and reserved spaces for wheelchair users allow for the physically impaired to enjoy opera, but there is still a remarkable portion of potential users whose impairment is sensorial. It is precisely when trying to make opera accessible to those - that is, to the blind and partially sighted and to the deaf and hardof-hearing — that opera and media accessibility meet.

Media accessibility is a growing subfield of Audiovisual Translation Studies which is gaining momentum, with multiple papers, research projects and conferences. Accessibility in relation to AVT features two prominent modalities - audio description (AD) and subtitling for the deaf and hard-of-hearing (SDH) - and can be defined according to Díaz-Cintas (2005: 4), as a way of "making an audiovisual programme available to people that otherwise could not have access to it, always bearing in mind a degree of impairment on the part of the receiver". In fact, as pointed out by the same author and demonstrated in the first part of this article, this notion of accessibility is shared by a traditional transfer which also overcomes a barrier, linguistic in this instance.

Regarding opera, it can be considered an audiovisual product which can be made accessible by different means: the blind and partially sighted can benefit from audio description (AD), audio introductions, audiosubtitling, and touch tours, whereas the deaf and hard-of-hearing can profit from subtitles and surtitles. These modalities will be described next making reference to the experience at the Barcelona opera house Liceu.

\subsection{Opera for the blind and visually impaired}

To date there are four different techniques to make opera available to those with sight problems. These are not exclusive, and we usually find that two or more techniques are used within one production.

\section{a) Audio introductions}

Talking Notes (York 2007) was the first enterprise to offer an audio text which described the opera production prior to the representation. Some venues such as London's ENO, Coliseum or ROH favour this system. Other opera houses across UK or Catalonia offer the possibility of downloading from a URL the audio introduction as an mp3 of the text, or the text in word format, plus an audio description of the opera on the day of the representation. Vocal Eyes in the UK or Teatre del Liceu in Barcelona offer this service before the actual performance begins and before every subsequent act, lasting 15 minutes in the former and about 5 minutes in the latter. The following text is the opening of Greg York's audio introduction for Werner Henze's Boulevard Solitude: 
Good evening - Gregory York here. Welcome to the Royal Opera House for tonight's performance of the work which launched the international career of Hans Werner Henze: Boulevard Solitude. This is the first time it's been staged by the Royal Opera, and its production this year marks the composer's 75th birthday. It's sponsored by The Jean Sainsbury Royal Opera House Fund and The Friends of Covent Garden. The conductor is Bernhard Kontarsky; the director is Nikolaus Lehnhoff, designs are by Tobias Hoheisel, and lighting by Paul Pyant.

It's a free version of Abbé Prévost's famous story of Manon Lescaut, and transposes the action to the seedy uncertain world of Paris immediately after the Second World War. The young couple, Manon and Armand des Grieux, meet in a railway station, and then find their lives descending into a downward spiral of sex, drugs and murder, when Manon's pimping brother, Lescaut, takes charge of his sister, and her wealthy protector, Monsieur Lilaque, becomes a victim.

The opera is divided into seven scenes separated by orchestral intermezzi, and the whole work is performed without a break, so there's no interval, of course; it runs for about an hour and a quarter altogether.

The designer, Tobias Hoheisel, has set the....

Compared to AD, York (2007) highlights various advantages with the use of audio introduction: one can hear the opera naturally because there is no need to wear a headset throughout the performance, which avoids interferences with the reception of the music and, at the same time with one's neighbours. And, most importantly, since audio introductions can be pre-recorded, they can be always available. Nevertheless, there are also a few setbacks, such as the strain on memory that is put due to the fact that everything has to be pre-described; the element of surprise is also removed, and neither improvisations nor curtain calls can be described.

\section{b) Audio descriptions}

Whereas audio introductions allow patrons to listen to the opera without intrusion from the describer, some firms such as Vocal Eyes or some opera houses such as the Liceu in Barcelona prefer to offer both audio introductions and opera $\mathrm{AD}$, in which the description of the visuals is intertwined in the gaps where lyrics are not generally heard and music is considered to be less important (Matamala 2005).

AD was the option chosen by the two blind associations which described operas at the Liceu from 2004 till 2007. Both the Catalan Association for the Blind and Visually Impaired ACCDV and the Spanish Association for the Blind ONCE signed an agreement with the Liceu and audio described many operas, even offering two different Catalan versions of the same (Rigoletto, L'elisir d'amore, La Gioconda, Semiramide, Otello, Ariodante, among others). Whilst the Catalan association for the blind aimed to deliver a complete audio description of everything, even if it meant treading on an aria or relevant music, the Spanish association tried to avoid overlapping on the lyrics. In view of the differing practices, the Liceu has commissioned the AD of operas in the 2007/08 season to researchers from the Universitat Autònoma de Barcelona (Cabeza 2007), who have tried to create a new style trying to combine all the existing practices both in Catalonia and abroad.

The first audio described opera was Andrea Chénier: an audio introduction was created and delivered live before the actual performance, a summary was read before every act, 
and an audio description that never impeded on lyrics was offered during the performance. Here is one excerpt from Andrea Chénier's AD, written by Cabeza, translated from Catalan into English:

- Catalan AD: La bella Maddalena entra en escena amb un senzill vestit de seda blanca i sense perruca. Gérard es queda bocabadat./ Maddalena s'asseu al test en una postura pensativa i arriba la comtessa, la seva mare, amb un pompós vestit amb tot d'ornaments $i$ una perruca voluminosa demanant que comencin els preparatius per a la festa.

- English Translation: The beautiful Maddalena goes on stage with a simple white silky dress, and without a wig. Gérard is astonished.// Maddalena sits on a flowerpot in a thinking position. Her mother, in a pompous dress full of ornaments and a voluminous wig, arrives and orders the preparations for the party to begin.

After the production a meeting was agreed between the describer and each association. The comments by the patrons revealed some interesting results (Cabeza 2007): whilst most members of one association were satisfied and highlighted the perfect synchronisation of the audio description, the other association complained because they wanted more information even if that meant impeding on the lyrics. This comes to show how previous experiences shape the habits of the audience.

The only common criticism was that the audio introduction put a strain on memory and was impossible to digest because the amount of information included was enormous. The solution has come in the form of recorded audio introductions that are available on the website and facilitate the comprehension of the plot not only to visually impaired patrons but also to everybody.

This first-hand experience in audio describing operas has allowed us to reflect on various challenges, such as the fact that opera $\mathrm{AD}$ is delivered live and even though the describer can view the performance several times, with the ability to take notes and work from a videotape copy or DVD in order to produce a pre-prepared script (Matamala 2007), changes and improvisations can occur, compelling the professional to adapt to what is taking place on stage. For example, in Andrea Chénier, Andrea sings while holding a blue book. The AD read "Andrea moves towards the right of Gérard and holds high above his head the blue book". But on the actual performance no book was to be seen. Another example in the same performance was after the duet between Andrea and Gérard. The night of the dress rehearsal - when AD was prepared -, after the duet in which Andrea ends on his right knee, there is a musical interval which thanks to the stage production created a great visual and emotional impact. As can be seen in Figure 4 the back panel is opened diagonally to portray the visual imagery of a tilted guillotine. In fact the guillotine is a leit motive of the production. At the end of the duet the stage was in total darkness and from the gap in the back panel an intense yellow light shone. The edges of the guillotine were highlighted and menacing. The back panel, with its shining opening moved very slowly towards the right of the stage and Andrea walked along the gap to create a chilling vision of a man walking at the edge of a sharp blade. In the plot we are not sure if Andrea will be sentenced to death. The AD had this description, and in fact on the actual night, the back panel moved shining its yellow gap towards the right, but Andrea remained on his knee holding Gérard's hand. This is the sort of improvisation which the $\mathrm{AD}$ faces in a live performance. 


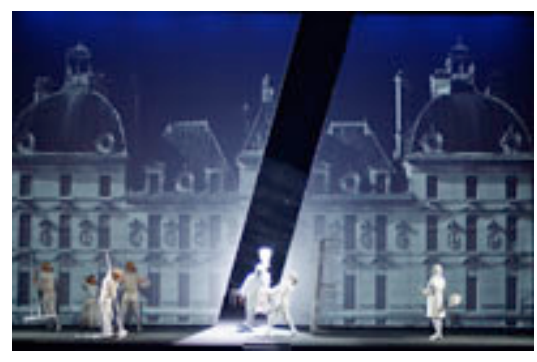

Fig. 4 Umberto Giordano’s Andrea Chenier

Another feature which has never been commented on is the fact that different musical performances have different tempo, so it is possible that the day of the performance when the $\mathrm{AD}$ is delivered the conductor decides to alter the tempo and the $\mathrm{AD}$ comments do not fit the already timed gaps. Nevertheless, compared to other live performances, opera is one of the easiest regarding delivery, since the music score helps with the timing of the narration.

\section{c) Audio subtitling}

As already stated, the main aim of an AD in opera is to bring together in a synthetic narration all the visual elements on stage such as movements, set design, costumes, props or facial expressions. However, there are other visual elements which are also part of the opera experience and which are available to opera goers: surtitles/subtitles. In other words, the blind and visually impaired people will be able to listen to the opera but, when sung in the original language, will not be able to understand the words. Subtitles or surtitles are the means offered to the general public to overcome this linguistic barrier, but are not useful to certain patrons due to their sensorial disability. One possibility is to summarise the content of the lyrics and include it in the traditional $\mathrm{AD}$, as in the following examples:

Example from Boulevard Solitude (audio described by Llorenç Blasi, 2006/07)

- Catalan surtitle: Truca a la policia, Jean.

- English translation: Call the police, Jean

- Catalan AD: Mana el criat a trucar la policia.

- English translation: He orders the servant to call the police.

Example from Aida (audio described by Cristóbal Cabeza, 2007/08)

- Catalan surtitles: Voldria el teu bell cel retornar-te,/les dolces brises del teu país,/ posar-te al cap reial corona/ i un tron alçar-te prop del sol.

- English translation: I would like to return you your beautiful sky,/ sweet breezes from your country,/ put a crown on your royal head,/ and set up a throne for your near the sun.

- Catalan AD: Ramadès canta com voldria tornar-li a Aida la llibertat i fer-la reina a prop del Sol.

- English translation: Ramades sings how he would like to give Aida back her freedom and make her queen near the sun.

Another possibility is adapting audio subtitling to opera. Audio subtitling involves reading aloud subtitles and it has been used in foreign TV programmes in the project "Spoken Subtitles" (Theunisz 2002) as a more economical accessible mode that uses a speech-synthesis software to convert text into speech, an output which is then converted into a signal which is decoded at home. This concept was transferred into the world of 
opera (Orero forthcoming) and tried by the Associació Catalana de Cecs i Disminuïts Visuals (ACCDV, Catalan Association for the Blind and Visually Impaired) in the concert version of Donizetti's opera Roberto Devereux. The describer read the comments on top of the music and singing and the results were very encouraging, as proved by the questionnaires answered by the patrons of the Catalan blind association. Moreover, the proximity of Catalan and Italian as Romance languages is such that audio subtitling created an overall effect of voice-over and a feeling of reassurance in the listener, who was able to follow the lyrics almost word by word.

However, this modality treads not only on music but also on lyrics and further research in the field of reception is needed in order to assess its usefulness: a wider array of users should be interviewed and other types of operas should be audio subtitled.

\section{d) Touch Tours}

Pre-performance tactile or touch tours are offered in some opera houses such as the Scottish Opera, San Diego Opera or the Grand Opera House in Belfast. In these tours patrons visit the stage and are encouraged to touch costumes and props in order to gain information about the actual production, an experience that has attracted even the sighted audience willing to know what happens offstage. Although no research has been carried out in this field, there is no doubt that touch tours enhance the reception of both the audio introduction and the audio description because patrons can relate what they hear to something they have personally felt.

\subsection{Opera for the deaf and hard-of-hearing}

Operas can be sung in the original language and, in order to overcome these linguistic barriers, opera houses usually offer surtitles or subtitles. As explained in Matamala \& Orero (2007), the Liceu projects surtitles in Catalan on a screen over the proscenium, as well as subtitles in Catalan, Spanish and English that can be followed at the back of every seat on a TFT screen. ${ }^{5}$ Surtitles are created by a translator from the opera original libretto, by editing the Catalan version of the libretto or by creating new ones following the stage interpretation. It is also the translator who decides during the performance the time a surtitle appears on the screen and when the new surtitle is projected, following the music score and the stage action. Since opera is a live performance there is room for changes and improvisation, making the presence of a person who times and projects the surtitles in real time absolutely essential.

Nevertheless, these surtitles and subtitles are conceived to overcome a linguistic barrier and are addressed to an audience that is not sensorially impaired. Hence, sound effects, unimportant lines or words repeated over and over are not surtitled and on some occasions, when the opera is sung in the language of the audience there are fewer captions because it is assumed that the audience can understand the words. ${ }^{6}$ This hinders the full reception of the opera by the deaf and hard-of-hearing and calls for an adaptation of surtitles: if adapted to the hard-of-hearing, the hearing audience will also benefit from these surtitles whilst surtitles only conceived for a general audience are not useful to the deaf and hard-of-hearing.

\footnotetext{
${ }^{5}$ Figaro's SimultextC (http://www.figaro-systems.com/installations.php) has also been installed in Teatro alla Scala, the Royal Opera House or Wiener Staatsoper.

${ }^{6}$ See http://www.deafweb.org/ga9706.htm [Retrieved 9 July 2007].
} 
Apart from surtitles and subtitles, some opera houses are offering signed operas ${ }^{7}$ : this is the case at London's Royal Opera House which in its current season has offered a signed performance of Tosca on July 12 2007, the English National Opera (ENO), that also signed the same opera in 2004 and the New York City Opera ${ }^{8}$, where The Cunning Little Vixen was also signed. In a signed performance, a sign language interpreter stands at the side of the stage throughout the opera and translates it to the deaf audience.

All these varieties of accessible opera might seem absurd for many people who consider signed language and surtitling obtrusive and annoying practices that hinder the full reception of the visual component - an argument also used by those who claim that subtitles distract the attention of the audience in films-, but the deaf and hard-ofhearing community include people who are partially able to hear, people who hear only certain frequencies and people who cannot hear anything at all but who can feel the vibrations of the orchestra, making opera an enjoyable experience for all of them. Moreover, assisted hearing systems are sometimes available in certain opera houses.

\section{Conclusions}

In conclusion, this article has demonstrated how opera is open to all through many techniques and translation modalities, both intrasemiotic and intersemiotic, both intralingual and interlingual. Operas are multimodal works which combine acoustic and visual elements: although some might claim that the various transfer modes presented affect or alter the original opera, the benefits are obvious: by means of translated libretti and/or surtitles the lyrics become comprehensible to a wider audience; by means of audio description, audio introductions and audio subtitling, the visuals are transmitted to the blind and visually impaired, and by means of surtitling/subtitling and sign language the words reach the deaf and hard-of-hearing. One can only hope that opera productions will aim to widen their audience even more and will include surtitlers and audio describers in their production teams.

\section{References}

Alonso Otero, Carlos (2000-2001) "La traducción de libretos de ópera". Vasos comunicantes 18: 82-83.

Apter, Ronnie (1985) “A Peculiar Burden: Some Technical Problems of Translating Opera for Performance in English”. META 30 (4): 309-319.

Apter, R. (1989) The Impossible Takes a Little Longer: Translating Opera Into English. Translation Review 30/31: 27-37.

Apter, Ronnie \& Mark Herman (1995) "The Worst Translations: Almost Any Opera in English”. Translation Review 48-49: 26-32.

Apter, Ronnie \& Mark Herman (2002) "Character Delineation in Opera Translations: Examples from Wagner's Ring". The ATA Chronicle 31: 5.

\footnotetext{
${ }^{7}$ Signed performances can be found here http://www.spit.org.uk/ and an online article on the topic is available here http://www.spit.org.uk/Newsletter/SPITNews37.pdf.

${ }^{8}$ topics.nytimes.com/top/reference/timestopics/subjects/s/sign_language/index.html?offset $=90 \& \& \&$
} 
Burton, Jonathan (forthcoming) "The Joy of Opera". In Anderman, Gunilla \& DíazCintas, Jorge (eds) Audiovisual Translation: Language Transfer on Screen. London: Palgrave Macmillan.

Burton, Jonathan \& Amanda Holden (2005) “Oper Übersetzen”, Die Horen. Zeitschrift für Literatur, Kunst und Kritik, 218: 124. Original English version, "Opera Translating", manuscript provided by the authors.

Cabeza, Cristóbal (2007) "Opera Audio Description: the Paradox". Paper delivered at the Media for All Conference in Leiria, November 2007.

Cohen-Levinas, Danielle (2004) "Décomposer le texte ou comment libérer la langue au XXe siècle". In Gottfried R. Marschall (ed) La traduction des livrets. Aspects théoriques et pragmatiques. Paris: Presses de 1’Université Paris-Sorbonne: 605-614.

Desblache, Lucile (2004) "Low Fidelity: Opera in Translation". Translating Today (1): 28-30.

Desblache, Lucile (2008) "Music to my ears, but words to my eyes? Text, opera and their audiences". LANS, Linguistica Antverpiensia NS6: 155-170.

Desblache, Lucile (forthcoming) "To Screen or not to Screen: challenges and rewards of libretto adaptation". Paper presented at the conference held at Roehampton University In So Many Words 2004.

Dewolf, Linda (2001) "Surtitling Operas. With Examples of Translations from German into French and Dutch". In Gambier Y. \& Henrik Gottlieb (eds) (Multi)Media Translation. Concepts, Practices, and Research. Amsterdam: John Benjamins: 179-188.

Díaz-Cintas, Jorge (2005) "Audiovisual Translation Today - A Question of Accessibility for All”. Translating Today, 4, July 2005, 3-5.

Durastanti, Sylvie (2004) "Surtitrer : enjeux, licences et contraintes". In Gottfried R. Marschall (ed) La traduction des livrets. Aspects théoriques et pragmatiques. Paris: Presses de 1’Université Paris-Sorbonne: 623-628.

Fenton, James (2003) "Textual Healing". The Guardian. Saturday June 142003 http://arts.guardian.co.uk/features/story/0,977062,00.html. Retrieved on 8th May 2007.

Gorlée, Dinda L. (1997) Intercode Translation: Words and Music in Opera. Target 9 (2): 235-270.

Hay, Josiane (1998) "Subtitling and surtitling”. In Gambier, Yves (ed.) Translating for the Media. Turku: University of Turku: 130-137.

Hurt, C. (1996) "Übertitel als Teil einer Operninszenierung amb Beispiel von Wagners Siegfried", in Christine Heiss \& Rosa Maria Bollettieri Bosinelli (eds) Traduzione multimediale per il cinema, la televisione e la scena: 85-94. 
Low, Peter (2002) "Surtitles for Opera: A Specialised Translating Task". Babel 48 (2): 97-110.

Matamala, Anna (2007) "La audiodescripción en directo". In Jiménez, Catalina (ed) Traducción y accesibilidad: la subtitulación para sordos y la audiodescripción para ciegos. Berlín: Peter Lang: 121-132.

Matamala, Anna (2005) "Live Audio Description in Catalonia", Translating Today, 4, July 2005: 9-11.

Matamala, Anna \& Pilar Orero (2007) "Accessible Opera in Catalan: Opera for All". In Díaz Cintas, Jorge; Pilar Orero \& Aline Remael (eds) Media for All: Subtitling for the Deaf, Audio Description and Sign Language. Amsterdam: Rodopi: 201-214.

Mateo, Marta (2002) "Los sobretítulos de ópera: dimensión técnica, textual, social ideológica". In John Sanderson (ed) Traductores para todo. Actas de las III Jornadas de doblaje y subtitulación. Alicante: Servicio de Publicaciones de la Universidad de Alicante: 51-73.

Mateo, Marta (1998) El debate en torno a la traducción de la ópera. In Orero, Pilar (ed) 1998. ACTES. III Congrés Internacional sobre Traducció. Barcelona: Universitat Autònoma de Barcelona: 209-222.

Nisato, Catherine (1999) "What's in an Opera? Wouldn't a Translation Sound as Sweet?". ATA Chronicle 28: 6.

Orero Pilar (forthcoming) "Audiosubtitling: A Possible Solution for OperaAccessibility in Catalonia”. TRADTERM. Universidade Estadual de São Paulo: São Paulo (Brasil).

Sario, Marjatta \& Susanna Oksanen (1996) "Le sur-titrage des opéras à l'Opéra national de Finlande". In Gambier, Yves (ed.) Les transferts linguistiques dans les médias audiovisuels. Villeneuve d'Ascq (Nord): Presses Universitaires du Septentrión: 185-193.

Spaeth, Sigmund (1915) “Translating to Music”. The Musical Quarterly 1: 291-298.

Theunisz, Mildred (2002) "Audiosubtitling: A new service in Netherlands making subtitling programmes accessible". http://www.sb-belang.nlç

Velly, Jean-Jacques (2004) "Le paradoxe d'Edipus Rex: traduire pour obscurcir, ou comment un texte asémantique peut être porteur de sense". In Gottfried R. Marschall (ed) La traduction des livrets. Aspects théoriques et pragmatiques. Paris: Presses de l’Université Paris-Sorbonne: 595-604.

Virkkunen, Riita (2004) “The Source Text of Opera Surtitles”, Meta XLIX (1): 89-97.

York, Greg (2007) "Verdi Made Visible. Audio-introduction for Opera and Ballet". In Jorge Díaz Cintas, Pilar Orero \& Aline Remael (eds) Media for All. Accessibility in Audiovisual Translation. Amsterdam: Rodopi: 215-229. 